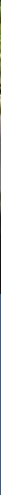

\title{
Justice in the forest: Rural livelihoods and forest law enforcement
}

\section{Key points}

- Forest Law Enforcement and Governance (FLEG) has become a favoured policy approach for addressing illegal logging. However, the social implications of this approach have not received much attention, in part because the extent of forest-based livelihoods is often under-appreciated.

- An exploratory survey of five countries shows how laws related to forests are often contradictory and restrict livelihoods. They tend to be selectively applied in favour of large-scale forestry and framed to favour dominant interests. As a result, the livelihoods of many forest-dependent poor people are rendered technically illegal.

- Law enforcement approaches that rely on cracking down on those using forests contrary to existing laws can reinforce social exclusion and entrench unjust laws and policy frameworks.

- Illegal forest use is often enmeshed in local and national political economies and systems of patronage. Addressing illegal logging without taking these patronage networks into account can be risky or counter-productive.

- Crude forest law enforcement measures often target small-scale violators rather than large, politically protected and illegal operators.
- Trade-based approaches designed to encourage law enforcement and discourage timber imports from illegal operations may ignore national realities and pay little attention to the social implications of enforcement.

- Future FLEG initiatives should:

- address all laws relating to forests and forestdependent peoples, and not just forestry laws.

- adopt a rights-based approach, giving due attention to strengthening human rights networks, improving the independence of the judiciary and encouraging community access to the law.

- be linked to governance reform programs aimed at creating public accountability and transparency in natural resource management.

- be developed through broad engagement with civil society organisations and based on real commitment to reform from national governments.

- correct unfair legal frameworks through participatory law reform.

- ensure even-handed enforcement so that the playing field is levelled in favour of rural communities.

- give greater scope for customary forest regulation.

- target major abusers, not small-scale operators.

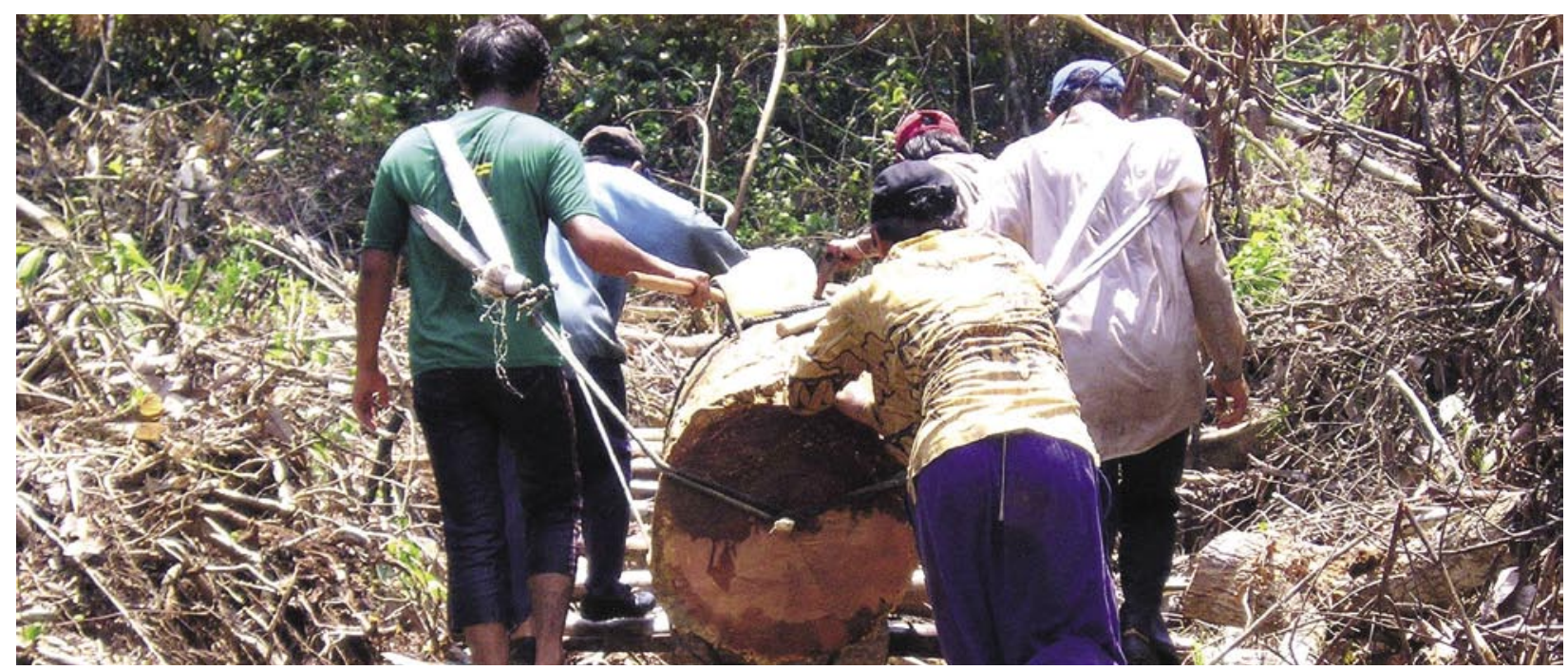

Over four-fifths of the timber harvested in Indonesia comes from illegal sources. Here, timber is extracted from a forest in Riau, Sumatra. Photo by Romain Pirard 
lands or 'state-owned' domains. The laws are frequently contradictory and incompatible, making the definition of what constitutes 'legal' forest use highly contentious.

The extent to which all these laws are applied varies widely, but commonly forest management laws that restrict access and use by local communities and give preferential access to large-scale forestry enterprises, are usually enforced more vigorously than complementary measures that recognise community rights. Even where procedures do exist by which communities can apply for secure rights, the procedures are commonly too onerous and costly to be widely used. Forest law enforcement initiatives tend to focus narrowly on compliance with forestry laws while neglecting laws that secure rural livelihoods.

History shows that favourable laws recognising indigenous and local community rights to land and forests have resulted from strong social mobilisation and use of the courts, but forestry laws have typically been heavily influenced by the timber industry lobby. In developing countries, international agencies have tended to push for laws that favour large-scale, highly capitalised forest industries, giving priority to sustainable forest management and generating state revenues, with much less emphasis on benefits for rural livelihoods. Community forestry has not been given much priority in policy-making but pressure from civil society and indigenous peoples has been crucial to the few gains that have been made.

\section{Webs of illegality}

Illegal forest use — such as illegal logging and bushmeat trading-is not just an outcome of poor governance and corruption, but an integral part of local and national political economies. Global demand for timber and burgeoning domestic markets are major drivers. Elaborate and deeply entrenched patronage systems facilitate, control and protect illegal forest use. The profits are woven into the fabric of society, keeping political parties and processes in operation.

Communities' lack of security contributes to their poverty, conflicts over resources, subsequent repression and human rights violations. The extent to which large-scale logging enterprises benefit or harm local communities is poorly documented. In general, benefitsharing schemes designed to share some profits from large-scale logging with local communities, function poorly. Much small-scale forest use is either 'illegal' or hard to keep legal because the requirements for community 'forest management plans' are onerous and local markets are flooded with cheap, illegal products, making legal produce uncompetitive. In some cases, the bureaucratic obstacles to regularising tenure, access and use rights facilitate the entry of 'fixers', who are members of illegal logging and poaching syndicates. In these situations, administrative decentralisation and community forestry schemes often result in communities getting further ensnared in webs of illegality.

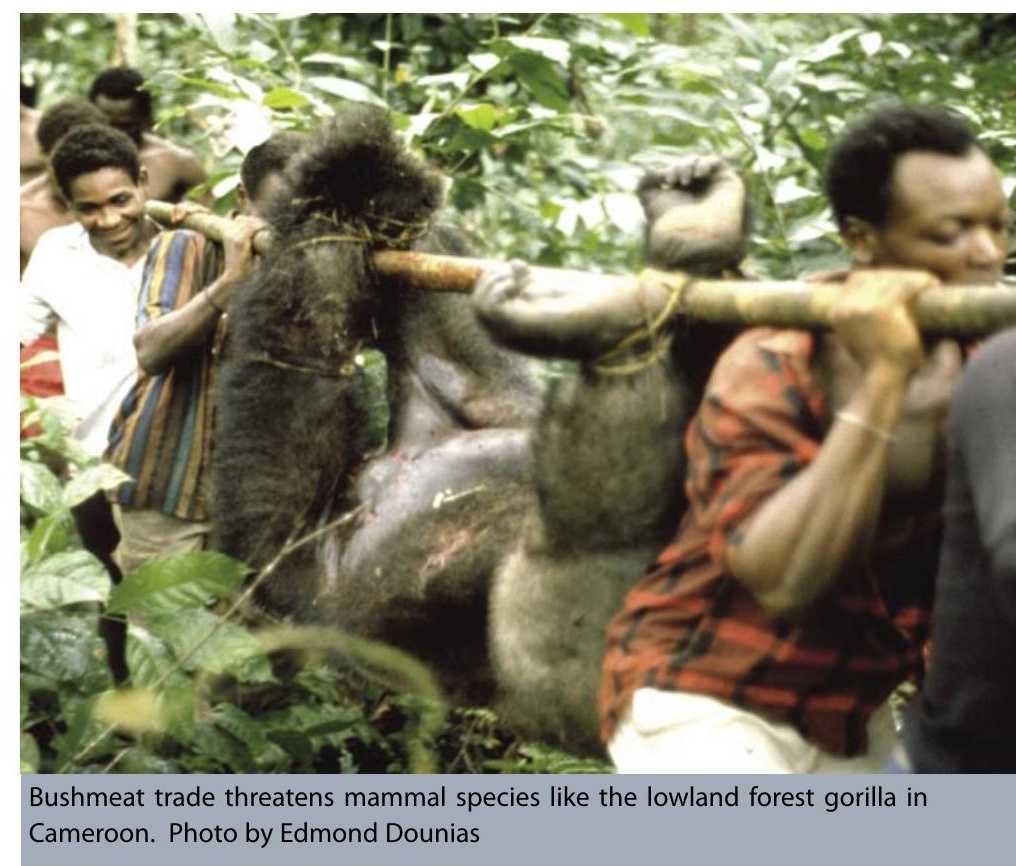

\section{Reinforcing social exclusion}

Enforcement efforts can usefully be analysed in terms of 'soft' enforcement, where compliance is encouraged by providing positive incentives, and 'hard' enforcement, including the criminalisation of violators. Good baseline data on current enforcement measures are lacking. Hard enforcement is ineffective where there are low penalties, weak institutional capacity, a non-independent judiciary or those charged with enforcement are complicit in illegalities. Laws designed to penalise individual criminals do not curb corporate misdemeanours or affect CEOs and shareholders. Crack-downs tend to target poor people and small-scale operators but avoid those who are well connected and politically protected. In some countries, mass expulsions of indigenous peoples and local communities from forests and protected areas have caused serious impoverishment.

Bilateral Memoranda of Understanding to curb the trade in illegal forest products, signed between the governments of exporting and importing countries, have stimulated vigorous national debates about forest 
law and policy. Although initial technical assessments have been unduly limited to forestry laws, ensuing discussions have helped to identify contradictions with other laws and the need for reforms to favour rural livelihoods. However, closing markets in importing countries may only shift illegal exports to less discriminating markets. Widespread enforcement of these market-based approaches will depend on 'legal verification' or 'step-wise certification', so that customs officials, procurement officers and retailers can discern which timbers are 'legal' and therefore acceptable. There is an evident risk that such measures may exclude consideration of the livelihoods of forestdependent peoples and may thus encourage forest management systems that create poverty rather than alleviate it.
Seeking to halt destructive forest use, environmentalists and development agencies are pushing for urgent changes to curb deforestation and combat poverty. Although illegal logging certainly contributes to forest destruction, the study suggests that in some cases forest law enforcement may not be the most appropriate response. This is because 'legal' forest use may be just as damaging to forests and local communities as illegal use. Current legal frameworks are often inadequate or contradictory and do not ensure sound or socially just forestry. In sum, forest law enforcement and governance initiatives may provide scope for pro-poor reforms, but they must be carried out in an inclusive, participatory, transparent and cross-sectoral way to ensure that they do not reinforce exclusionary approaches that harm the tens of millions of people whose livelihoods depend on forests.

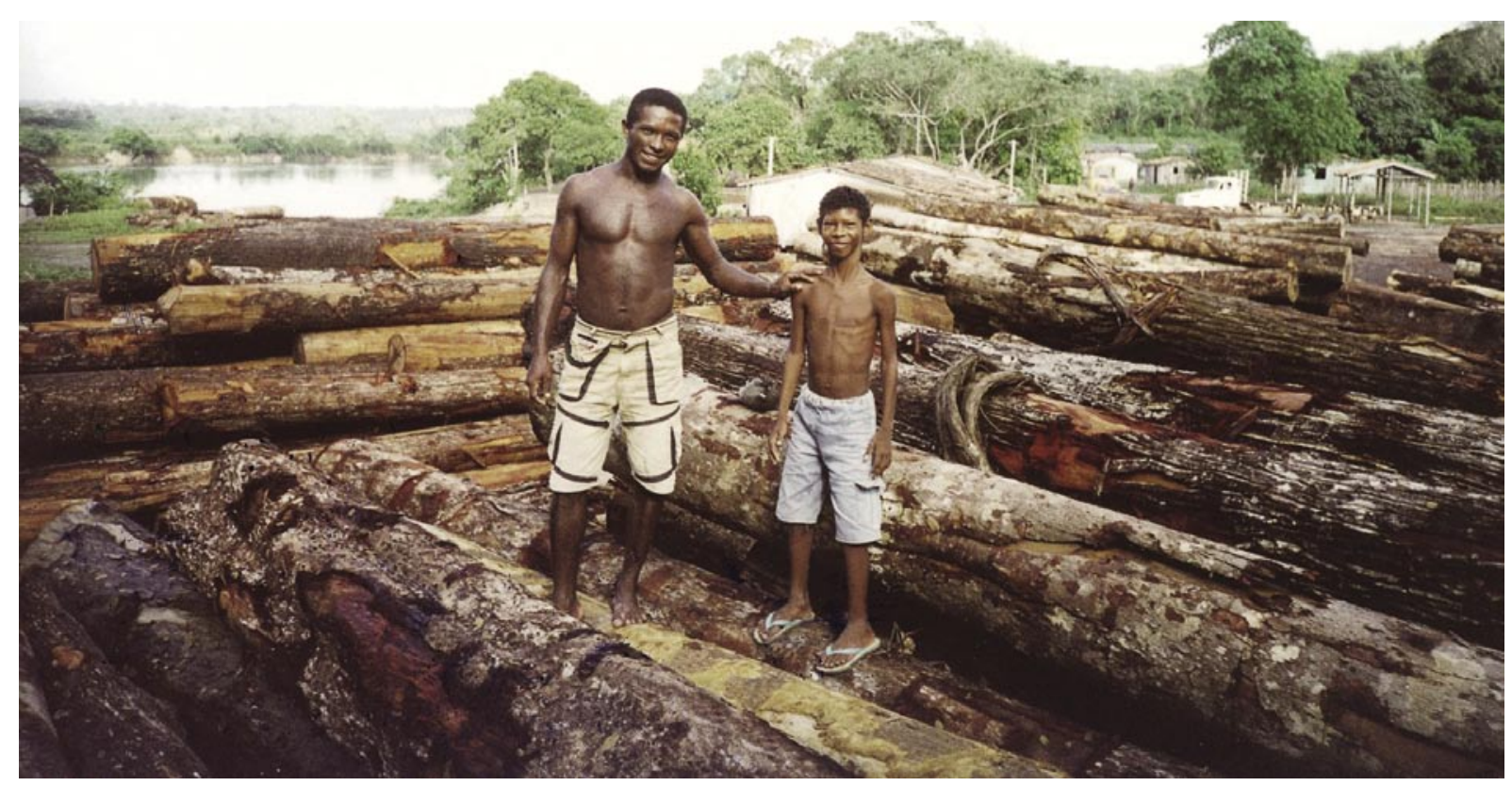

Logging in communities along the Capim River, Eastern Amazonia. Photo by Gabriel Medina
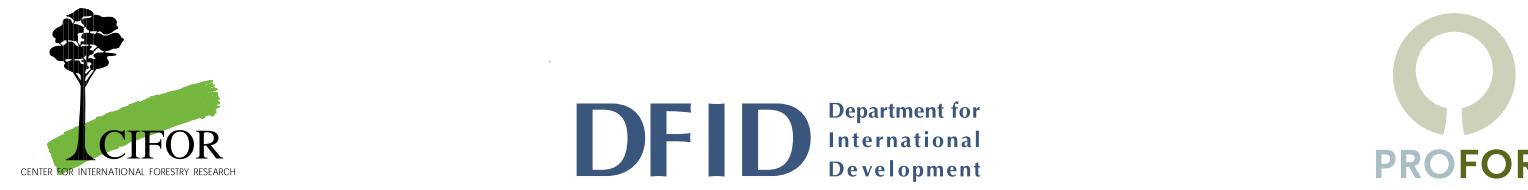

Developmen

PROFOR

* This Infobrief is based on Justice in the forest: Rural

livelihoods and forest law enforcement by Colchester, M. et al.

CIFOR Forest Perspectives No. 3. CIFOR, Bogor, Indonesia.
Center for International Forestry Research

office: Jalan CIFOR, Situ Gede, Sindang Barang, Bogor Barat 16680, Indonesia. mailing: P.O. Box. 6596 JKPWB, Jakarta 10065, Indonesia Tel: +62(251) 622622 Fax: +62(251) 622100

E-mail: cifor@cgiar.org Website: www.cifor.cgiar.org

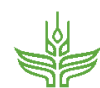

CGIAR

$F \cup T \cup R E^{: *}$ HAR $\ /$ E S T 